\title{
The Five Ancient Criteria of Democracy: The Apotheosis of Equality
}

\author{
By Gregory T. Papanikos*
}

\begin{abstract}
Democracy in ancient Athens was different from what is implemented today even in the most advanced democracies. To evaluate this difference, this paper presents five criteria of democracy and then applies them to ancient Athens and modern advanced democracies. In comparison and according to five criteria, modern democracies are inferior to what the eligible citizens of Ancient Athens enjoyed. The ancient Greek literature on the subject has identified five criteria of democracy which neither today nor in ancient times were fully satisfied. The democracy today satisfies some but not all five criteria. This was also true for the ancient (Athenian) democracy. They differ in which criteria they satisfied. Of course, each criterion is fulfilled to a certain extent and this may differentiate modern from ancient democracy. These issues are discussed in this paper.
\end{abstract}

\section{Introduction}

Democracy is a political system which was applied for the first time in ancient Athens in the $5^{\text {th }}$ century BCE. People would gather together in a location, which was usually called agora, to do something in common. In the centuries preceding the $5^{\text {th }}$ century $\mathrm{BCE}$, these gatherings most probably served the purpose of the ruler (king), where announcements would be made about some important events. At the same time, judging from people's reactions, he could get an idea of what they thought. I have examined elsewhere ten such meetings which are mentioned in Papanikos (2021). ${ }^{1}$ All these were far from being considered meetings of a city-state which was ruled by democracy.

This brings us to the issue discussed in this paper. What is democracy? This is discussed in the next section. What are the criteria to evaluate whether a political system is democratic or not? Reading the ancient literature, I have discerned five criteria of democracy which are discussed in five consecutive sections. These are isegoria, isonomy, isocracy, isoteleia and isopoliteia. The final section of the paper gives a synopsis of what was covered in the paper.

"President, Athens Institute for Education and Research, Greece; Honorary Professor of Economics, University of Stirling, UK; and Professor, MLC Ljubljana, Slovenia.

1. G. T. Papanikos, "Collective Decision-Making in Homer's Odyssey," Athens Journal of Mediterranean Studies 7, no. 1 (2021): 59-84. 


\section{Democracy Defined}

In 431 BCE, Thucydides, ${ }^{2}$ citing Pericles' Funeral Oration on the occasion of honoring the first dead of the Peloponnesian War, defined the political system of ancient Athens as follows:

"... and the name is called democracy because not the few but the many rule"

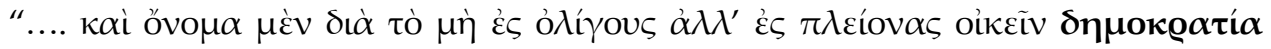

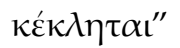

Before this definition is analyzed, it should be mentioned that this was not the first time the word democracy was used in a document, but this was the definition everybody cites when a reference is made to the beginning of democracy.

Herodotus, writing in $440 \mathrm{BCE}$, was most probably the first to use the term both as a noun and as a verb. The first mentioning of the word democracy is in Book 3 (Thaleia) of his 9-books history (later called by the names of the nine muses). The word $\varphi v \lambda \dot{\alpha} \varsigma$ is translated here with the word clan and not with the word race:

"...from this marriage Cleisthenes was born who established the clans and democracy in Athens" (Bold emphasis added)

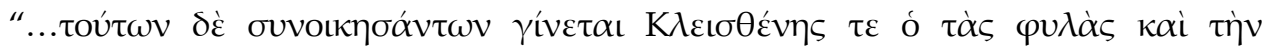

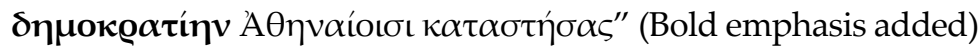

And in Book 6 (Erato), Herodotus states:

“...here I should mention a greatest thing happened not to be believed by Greeks that Otanes expressed the opinion to the seven that Persia ought to be democratized. Mardonius abolish the Tyrants of Ionia and established democracy in the cities" (bold emphasis added).

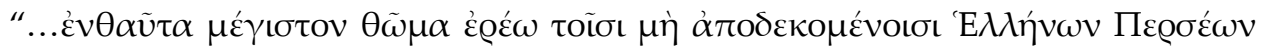

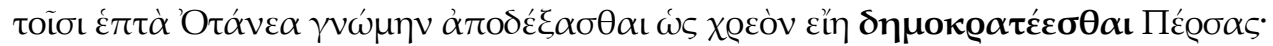

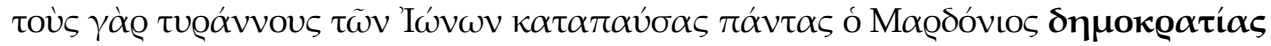

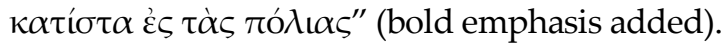

2. Thucydides was writing history which he thought would be useful for all future generations because people tend to make the same mistakes over and over again. He made the strong assumption that people learn from their mistakes, especially the people of a democratic politeia. They do not. On the issue of history see Papanikos, $\triangle \dot{\varepsilon} \kappa \alpha M \alpha \theta \dot{\eta} \mu \alpha \tau \alpha$ $\triangle \eta \mu о к \rho \alpha \tau i \alpha \varsigma$ (Athens: ATINER, 2021); Papanikos, The Use of History as a Tool of PolicyMaking. (Mimeo, 2006); Papanikos, The Use of European History: Lessons for the 21st Century History (Mimeo, 2005). These historical issues have been also discussed in Papanikos and N. C. J. Pappas, European History: Lessons for the 21st Century. Essays from the 3rd International Conference on European History (Athens: ATINER, 2006). 
Two words in Pericles' definition have led to too many misunderstandings:

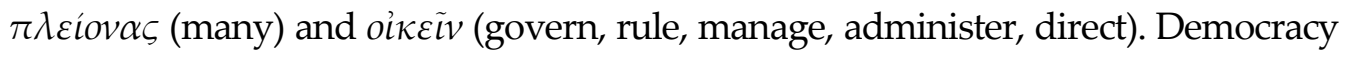

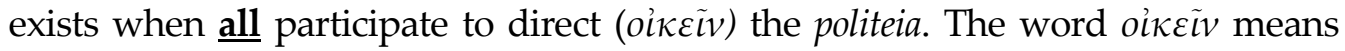
that all directly (not through representatives) manage their politeia, e.g., its economy, its military, its erection of monuments of arts and worship, and its organization of religious, athletic, and educational festivities. In other words, all people govern and there is no need for anybody to govern for the people. ${ }^{3}$ Without the all, the many does not define democracy.

As it stands in the excerpt of Pericles, the word "many" is unfortunate because it gives rise to two interpretations. The first relates to the ever-present political mechanism of majority voting in electing representatives and/or rulers ${ }^{4}$ by all eligible citizens or decision making by any political organ, e.g., the parliament. It is a system where elected "representatives" of the people decide and rule on their behalf for a relatively long period of time which would have been considered contradictory to democracy, not only in ancient Athens, but also in such oligarchic political systems such as that of ancient Sparta. In ancient Athens, such a political system of ruling (oikeiv) through "representatives" (a government for the people) would have been considered a mockery of democracy. Similarly, there is no such thing as "indirect" democracy. By its own merit, the word democracy means "direct," and there is no such thing as indirectly direct.

Apart from the misuse of the term democracy when the adjective "representative" is used, the word democracy has been abused by monarchies which call themselves democracies! Even worse, brutal dictators who stay in power for all their lives call their political system democracy, sometimes even a "people's" democracy. Many atrocities have been made in the name of people's democratic rule. This would have been ridiculous and outrageous in ancient Athens. Of course, a monarchy or a dictatorship can be a very good political system and a monarch or a dictator may be an excellent ruler, but it should be

3. In his Gettysburg Address (the Funeral Oration of the dead of the American Civil War in 1863), Abraham Lincoln, similar to Pericles' Funeral Oration, stated the famous phrase: "Government of the people, by the people, for the people, shall not perish from the Earth." Many use this phrase as a praise of democracy. It is not. In a democracy there is no such thing as "for the people". There was nothing "for the people" in ancient Athens. By definition, democracy was and is the people! Again, it should be mentioned that democracy is not necessarily the best of all available alternatives. It is absurd, though, to call something democracy when it is not.

4. In many cases not even this is satisfied. In the 2016 USA presidential elections, the majority of the votes were casted for the candidate who was not elected. In 1963 the same occurred in Greece. The political party which obtained the relative majority of votes had fewer seats in the Greek Parliament and could not form a government. Modern "democracy" at its best! In both cases, the electoral law was applied. The system was legal; its political system was not a democracy. 
clearly mentioned: it is not a democracy! It can be called a benevolent monarchy (dictatorship).

The second interpretation is considered as the authentic definition of democracy. If one reads the Funeral Oration carefully, it will come to the conclusion that Pericles meant that in a democracy all and not many $(\pi \lambda$ ciov $\alpha \varsigma)$ must

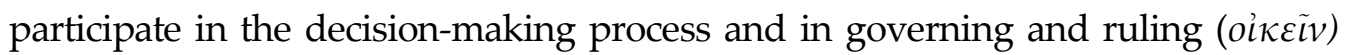
their politeia. It was in the middle of the $5^{\text {th }}$ century BCE that, at last, all citizens of Athens could be elected (chosen, drawn) to all offices (archonships) without any exception.

Democracy exists when all citizens participate to decide on every issue relating to the direction and government of their politeia. And of course, decisions on every issue are taken by all citizens by majority voting. The word "many" does not mean majority voting for representatives (elect "political animals"), but majority voting to decide on specific issues (choose "inanimate beings") and govern (direct) the everyday affairs with the participation of all citizens.

As in many contemporary political systems, in ancient Athens, majority voting at the level of the ecclesia of demos could change neither the fundamental

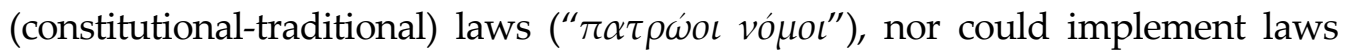
which were against a minority. Actually, the ecclesia of demos voted on resolutions $(\psi \eta \varphi i \sigma \mu \alpha \tau \alpha)$ and not so much on laws. If someone wanted to change a law, he had to first request the permission of the ecclesia of demos with at least 6,000 casted votes (about $1 / 3$ to $1 / 4$ of the total members of the ecclesia of demos) to obtain the right to propose a law change. For those who did not follow this rule, there were harsh punishments, including the death penalty. In ancient Athens, this "illegal" process of changing the laws was called $\gamma \rho \alpha \varphi \eta \tilde{\eta} \alpha \rho \alpha v o ́ \mu \omega v$.

The above also explains why there was no need to distinguish the executive power (government), the legislature power and the judiciary. All these functions were performed by the full participation of all eligible citizens. This is not true in monarchies and oligarchies, albeit under certain circumstances these could be much better political systems than a democracy.

\section{Isegoria}

In ancient Athens, when the general assembly of eligible citizens convened (called ecclesia of demos), the herald would open up the deliberations, announcing

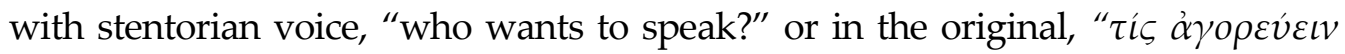

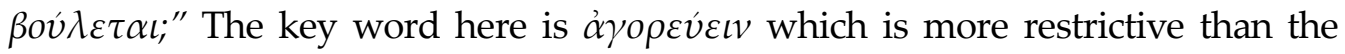
word "to speak," and means "speak in the agora". After all, even the non-citizens living and working in Athens such as slaves and metics could freely speak, as is mentioned by Xenophon. ${ }^{5}$ Speaking in the agora was a political right. Speaking

5. Xenophon (Pseudo), Athineon Politeia (5 ${ }^{\text {th }}$ century BCE), i12. 
elsewhere was a social privilege. Citizens had the political right to address the assembly of eligible citizens who then would decide by voting, after listening to all speakers on the issues listed in the meeting's agenda. Thus, isegoria exists not only if you can speak, but if others who decide listen.

Many confuse isegoria with the wide-ranging ideal of freedom of speech and freedom of expression. ${ }^{6}$ Such freedoms are definitely a characteristic of democracy, but where and when this right is exercised distinguishes a democracy from a nondemocracy. In a democracy, isegoria means the right of every eligible citizen to speak freely and frankly only before a political body that matters, i.e., the ecclesia of demos, at a specified time and place, with a specific agenda and a welldetermined audience (eligible citizens). The ecclesia of demos decides on all political issues and appoints rulers of the politeia with the participation of all citizens. In ancient Athens, democracy meant freedom to decide, or in the words of Pericles, "... we freely decide for our common things." 7

Thus, isegoria requires three things. Firstly, it demands freedom to speak not just anywhere, but before the political organ (institution) that decides and rules. Secondly, all eligible citizens must participate in this body, otherwise it is not a democracy. Thirdly, all must have the right to vote freely during the specific deliberations of this political organ for all the issues that relate to the ruling, governing, directing, and managing of their politeia.

Today many confuse the meaning of isegoria with the lack of censorship. The freedom of press is a manifestation of this misunderstanding. Actually, the socalled freedom of press violates the criterion of isegoria because (a) the audience of the mass media (press) neither decides nor rules, at least directly (b) each citizen does not have the same right or probability to appear in the mass media and (c) the audience is not what should be in a democracy.

The ancient Athenian who spoke in the Pnyx (the place under the Parthenon where the ecclesia of demos was convening) was free to speak, but most importantly to be listened by all those, who, at the end, would vote on a specific issue, e.g., go to war. Speaking without the relevant (decision-making) audience to listen is not what was meant by isegoria. In contrast, today freedom of expression is meant by being able to speak at any place, at any time and through any medium. The question is who listens? This is far from what the ancient Athenians meant by isegoria. In ancient Athens, democracy and freedom to decide on political issues went hand in hand. Today freedom to speak does not extend to the freedom to decide on each and every single political issue or a "common thing" in Pericles'

6. In ancient and modern Greek, the word $\pi \alpha \rho \rho \eta \sigma i \alpha$ is used to describe the right of free speech with courage and frankness. If people do not express their opinion with $\tau \alpha \rho \rho \eta \sigma i \alpha$, should they be allowed to have the right to speak? In a democracy they should not.

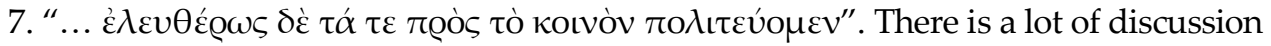
of the concept of freedom, both its negative (private life) and positive (public life) aspect. This is important, but goes beyond the scope of the arguments made here. 
words. Instead, the freedom is restricted to elect someone who, for many years, will decide on behalf of the citizens for each and every issue of concern to all. These elected representatives have the freedom to speak before a political body which decides, e.g., a parliament, a congress.

In a democracy, freedom to speak in public should not be allowed anywhere, ${ }^{8}$ but only in the ecclesia of demos. This is the political body eligible to make decisions with the participation of all citizens. Those who speak in the mass media are decided by an oligarchy. This definitely is not what is meant by isegoria in a democracy. Mass media's "audience" includes non-eligible citizens which is another violation of isegoria. The audience of the so-called "free" media and "free" press cannot be identified as the decisive and ruling political body for many reasons, most importantly the exclusion of children. For pedagogical purposes, children should not be allowed to participate in the deliberations of the "free" press. After all, Socrates had the freedom to speak in the Athenian ecclesia of demos, but did not have the right to "corrupt" the youth, i.e., the freedom to publicly speak to a young audience.

It can be argued that the so-called "free" press today corrupts not only the youth, but all citizens. The "free" press speaks without $\pi \alpha \rho \rho \eta \sigma i \alpha$, as this was meant by Isocrates, i.e., with impunity, and not as it was meant in Euripides and Demosthenes, i.e., frankness and straightness. The most important manifestation of this corruption is fake news that started as a joke in New York in 1938, continued as a tragedy with Hitler's Minister of Public Enlightenment and Propaganda, Joseph Goebbels, and has come full circle today with news that are tragically comic, which use sophisticated techniques of "enlightening" the public. Unfortunately, many people, without gnosis and virtue, believe and use these "news" because the audience is similar to what pseudo-Xenophon was describing 2,500 years ago for the ancient Athens ecclesia of demos: $\dot{\varepsilon} \nu \delta \dot{\varepsilon} \tau \tilde{\omega} \delta \eta \dot{\eta} \mu \dot{\alpha} \mu \alpha \theta \dot{\alpha} \alpha \tau \varepsilon$

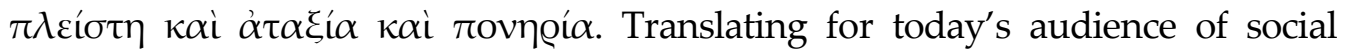
media, radios, televisions and newspapers: the audience of the mass media $(\delta \eta \mu \omega)$ is

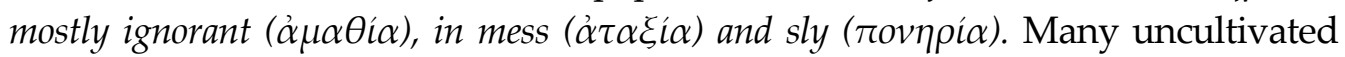
and ignorant citizens do not have the virtue (arete) to choose between real and fake news. In addition, most of them feel comfortable with fake news because they square well with their own ignorance and most importantly with their own prejudices. In a democracy, citizens without gnosis must be excluded from deciding and ruling. Of course, citizens can choose to remain ignorant, but they should not be allowed to rule, to govern, to manage and to direct the politeia.

8. There is a good and simple reason for this. If public speaking in a restricted audience includes arguments against other people who are not there, then the whole process violates the criterion of isegoria because the people who are "accused" as holding an opposite view are not there to defend themselves and their views. Today this has taken a dramatic twist with the fake and manipulated news that circulate through the social media with a speed that the ancient God Hermes would envy. 
However, fake news is not a new phenomenon. Its technology has been changing. In ancient Athens, the spread of fake news might have been slower, but the damage was as dire as it is today. The eighth character, out of thirty, of Theophrastus referred to the people who spread fake news. He called fake news

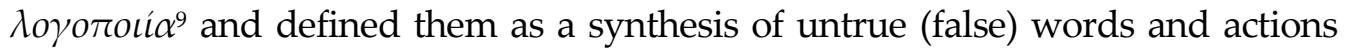
whom the spreader wishes to be believed. ${ }^{10}$ The interesting thing is that immediately Theophrastus provides an example of a spreader which is not gossiping, but fake news about a military operation.

A final comment on isegoria relates to freedom of thought. In ancient Athens, as in modern democracies, the eligibility of citizens to speak in the assembly was determined by age, gender and citizenship status. Only Athenian male citizens above a certain age were eligible to participate, speak and vote. The only training required was a military service. However, Plato was first to point out in the fourth century BCE, followed by John Stuart Mill in the $19^{\text {th }}$ century and John Dewey in the $20^{\text {th }}$ century, that isegoria (democracy) without education was not possible. Knowledge is what makes people free from any superstitions and ignorance. Isegoria requires freedom of thought and this can be obtained only through education.

Isegoria is so important that it is used to define democracy itself. If this criterion of democracy is satisfied, then there is no need for the "masses" to get wild $(\dot{\alpha} \tau \alpha \xi i \alpha)$. The criterion of isegoria implies that there is no need to organize political demonstrations and political gatherings of any kind because every citizen has the right and the opportunity to speak before the largest and most important political congregation ever, i.e., the ecclesia of demos. No need to demonstrate or lobby. No need for civil disobedience. No need for filibusters in the representative political bodies. Isegoria makes these mechanisms to affect decisions and make rulings obsolete and they should be abolished.

Isegoria gives the right to all citizens to participate in a decisive political body, but also the opportunity to persuade the ecclesia of demos to take a particular course of action in order to rule the politeia. For example, going or not to war is an important decision, and in a democracy, this must be taken only by the ecclesia of demos. Similarly, the USA President's executive order to ban immigration could be the result of a decision made by the eligible USA citizens. No pressure groups (lobby) are needed if the ecclesia of demos does its duty which is what is required from a democracy. All important issues can be debated and voted upon by all eligible citizens. According to isegoria all those who want to speak will speak. Today this can be achieved through the technology of the internet and social

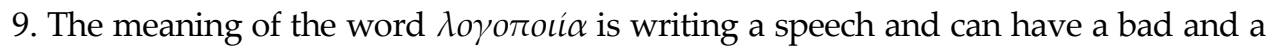
good connotation. A bad connotation implies writing something which is not-true.

10. I translated this paragraph from Theophrastus, Characters $\left(8^{\text {th }}\right.$ character) " $\mathrm{H} \delta \dot{\varepsilon}$

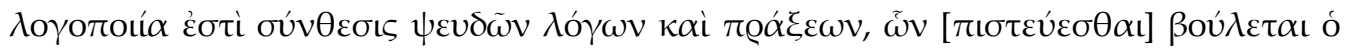
$\lambda о \gamma о \pi о เ \tilde{\omega} v^{\prime \prime}$. 
media, if they are organized to serve a contemporary virtual ecclesia of demos. In a way, everybody can "demonstrate" and "lobby" for his/her opinion on the issue from the comfort of his home without the need of a physical presence.

\section{Isonomy}

Isonomy means that all citizens must be equal before the law. The word isonomy is a compound word. The word iso means equal and is widely used in Greek as well as in the English language. The word nomos has two interpretations. The first has a straightforward interpretation and means the law. Thus, isonomy meant that everybody is equal before the law. The second interpretation of nomos is more complicated and it can mean share, distribute, and allocate. The question is, equal share of what? Some would argue that it means an equal distribution of (political) power. Thus, it is another word of (synonymous to) democracy. Notwithstanding these arguments, isonomy here is interpreted as equality before the law.

In ancient Athens, there was a clear distinction between private and public life. In his Funeral Oration, Pericles states that in Athens, "...all citizens are equal before the law for their private differences."11 Democracy must also guarantee that all citizens and non-citizens alike are equal before the law. In ancient Athens, noncitizens (metoikoi ${ }^{12}$ and douloi ${ }^{13}$ ) were equal before the law for their private affairs with citizens and non-citizens. With few exceptions, such as ostracism, the ecclesia of demos could not adopt a law which applied to one man only $\left(\varepsilon \pi^{\prime} \alpha v \delta \rho \hat{\imath}\right)$. And in any case, ostracism was only for the male Athenian citizens. Athenian citizens had other obligations as well such as serving as soldiers and fighting and dying for their homeland. Being a citizen had privileges, but obligations as well.

To a certain extent, most contemporary, advanced countries satisfy the criterion of isonomy, but by itself does not determine the existence of democracy. Isonomy can exist in oligarchic and monarchic political systems as well. Ancient Sparta had isonomy. The rule of law is a necessary, but not a sufficient, condition for a democracy. For example, a monarch or a tyrant can guarantee isonomy for all of its subjects. In ancient Athens, Peisistratus, as Aristotle mentions in his Athenian Politeia and Herodotus in his History Books, was a tyrant (dictator) very

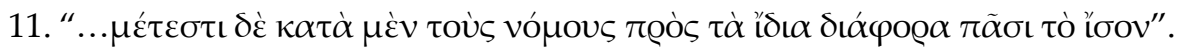

12. Similar to what landed immigrants are today in many advanced countries.

13. This is translated as slaves, but in Ancient Athens the word meant work as it still does today in modern Greek. Pseudo-Xenophon writing about the Athenian Politeia around 420s BCE "complaints" that citizens in the Athenian democracy could not mistreat them (metoikoi and douloi) because they dress the same way as the citizens and there is the danger to mistake some citizens as metoikoi or douloi. 
popular during his rule because he applied isonomy. ${ }^{14}$ In some cases, he even discriminated in favor of the poor and against the rich, which some people would consider, for some unexplained reasons, fair. Actually, in Sparta--an oligarchic system with two kings--the rule of law was stronger and was respected by all, especially by the archons. ${ }^{15}$ Some authoritarian regimes are better suited to apply the rule of law and of course isonomy, especially in protecting all citizens from criminal activities.

In contemporary advanced societies, the biggest threat to isonomy does not normally come from the political process itself, but from the judiciary. Since antiquity, corruption of judges existed in both democracies and non-democracies. It is well known that Hesiod's inspiration to write his monumental work in the mid- $8^{\text {th }}$ century BCE was a response to corrupted archons (kings), who, at the time, served as judges as well. Hesiod writes the following in his Works and Days referring to a property dispute with his brother: ${ }^{16}$

"... many you seize by bribing the judges who this way they want to judge"

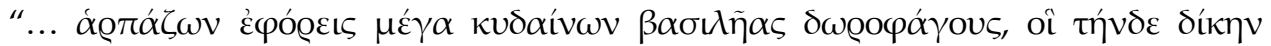

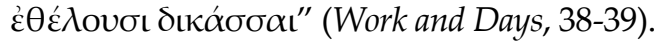

How then can citizens be protected from corrupted judges? In ancient Athens, during the democracy years, an exemplary way was found to account for corrupted judges. They made the cost of corruption unbearably high because of the large number of citizens who served as judges. In addition, judges were not known beforehand. They were drawn from a list of 6,000 eligible citizens in the morning of the court hearings. This procedure made the transaction and monetary cost of bribing the judges prohibitive. Moreover, and most importantly, an attempt by a litigant to bribe judges could not be kept secret, if someone attempted to bribe all 6,000 judges. This system assured as much isonomy as one can get from judges. And from the history of ancient Athens, during its glorious years of democracy, there is no serious report of a court decision which was the result of bribing the

14. Aristotle, Athineon Politeia (4th century BCE); Herodotus, Histories (Istoriais) $\left(5^{\text {th }}\right.$ century BCE).

15. Xenophon, in his Lacedaemonian Politeia, wrote, "But everyone knows that in

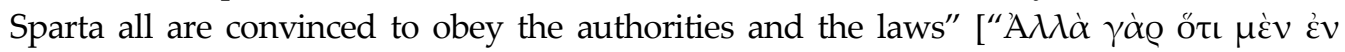

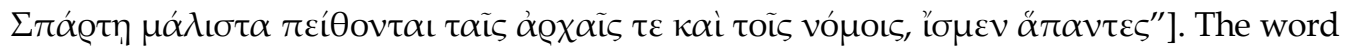
$\pi \varepsilon i \theta o v \tau \alpha \iota$ is translated as "convinced to obey" as opposed to "obey" only because this better express the meaning of what Xenophon explained in Chapter 8 of his book where this quote comes from.

16. Most classicists agree that Hesiod was contemporary to Homer and date both of them around the mid- $8^{\text {th }}$ century BCE. Homer's political world was that of a monarchy. Hesiod's Works and Days can be interpreted as a challenge to the power of monarchs. Hesiod's warns the monarchs to be fair because the mighty Gods have an eye on them. 
judges. There are many though who criticized decisions taken by judges implying wrongdoings, especially in comedies played in the Athenian theaters.

In ancient Athens, as in the present world, protection from lawyers was not possible. The rich could buy the services of skilled lawyers, called orators ( the Athenian court. On the other hand, the rich were subject to an unusual type of unfair treatment. Athenian judges were particularly harsh in fining the rich because their stipend, as judges, depended on these fines.

In concluding this section, it should be emphasized that the difference between isonomy in ancient Athens and in contemporary political systems is a difference of degree and not of qualitative substance.

\section{Isoteleia}

Organized societies exist because they provide specific services to their citizens. This is the beginning of Aristotle's book on Politics. ${ }^{17}$ Societies must spend on what is called "public goods". Isoteleia requires that all citizens ought to contribute to public spending proportional to their income and wealth (property), but a politeia can find other revenue sources as well. This is well documented in Xenophon's excellent book on Public Revenue Sources (Пó $\rho \circ) .{ }^{18}$ Two centuries earlier, Solon's reforms in the $6^{\text {th }}$ century BCE were based on wealth (income).$^{19}$ He grouped all citizens into four classes based on wealth (income) and not on heredity. Each class had specific economic obligations to the politeia. Similarly, their political rights as citizens were different. The American Revolution's "No Taxation without Representation" was in Solon's years, "Representation Analogous to Taxation".

A large portion of public spending in ancient Athens was allocated to defense, to public infrastructure and to cultural activities. In a democracy, isoteleia implies that public money is used efficiently, effectively and with transparency. This was guaranteed by the unique process which existed in ancient Athens to finance major public works. The rich of ancient Athens were obliged to finance the building and the maintenance of military equipment (naval ships, horses, weapons etc.) and bear the costs of various educational (cultural), sport and

17. Aristotle, Politics ( $4^{\text {th }}$ century BCE).

18. Xenophon, Revenue Sources (Poroi) (4th century BCE).

19. Taxes on wealth have been debated ever since the Solon's years. In political circumstances where tax evasion is ubiquitous, taxing wealth is the best tax policy. On this issue see Papanikos, "Taxing Wealth and Only Wealth in an Advanced Economy with an Oversized Informal Economy and Vast Tax Evasion: The Case of Greece," Vierteljahrshefte zur Wirtschaftsforschung, DIW Berlin 84, no. 3 (2015): 85-106, for a modern application of Solon's tax system. 
religious festivities called liturgies. This direct way of financing public spending improved the efficiency, the effectiveness, the competitiveness and the democracy (transparency) of public spending. ${ }^{20}$

This reduced the misuse of rich people's taxes because public spending on a particular item was directly managed by the one who paid for it. As a matter of tax fairness (isoteleia), the rich could claim that they were other Athenians, richer than themselves, who could pay more or bear the burden of financing a public project. In this case, it was possible to have an exchange of properties. Anyone who claimed that they were not as rich as someone else would be asked to exchange his property with him. This was an excellent way of evaluating and comparing wealth among Athenian citizens.

Isoteleia is another issue which modern political systems' performance can be considered acceptable even though there is no perfect tax system. In the relevant literature of democracy, isoteleia does not attract the attention of the other three criteria. This is unfortunate because, in a democracy, isoteleia plays another more important role. Given that all citizens must participate in the decision-making process and in ruling (managing, governing) their politeia, penury should not prevent them from doing so. Poor citizens must be compensated for the loss of their labor income when they serve their politeia as members of the ecclesia of demos and/or as one of the many archons and judges. In today's economic jargon, in a democracy, isoteleia must include a negative income tax, i.e., subsidies and wages to participate in the decision-making process and in serving as archons. In ancient Athens, during the years of its golden age of democracy, circa mid- $5^{\text {th }}$ century BCE, all citizens were compensated to participate in the ecclesia of demos.

In conclusion, democracy without isoteleia is not possible. However, there is a negative aspect to it as well. If isoteleia permits the participation of citizens with low opportunity cost (poor unemployed people), then the effect of the lack of pedagogy on democracy becomes evident and very perilous. The best way to describe it is using the words of Pseudo-Xenophon in his Athenian Politeia of 420s BCE:

...in the masses mostly exists ignorance and mess and slyness: penury leads to obscenities and to rudeness and to ignorance because some people lack money

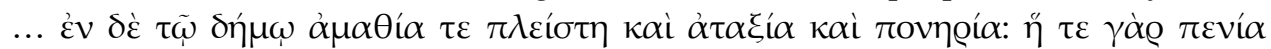

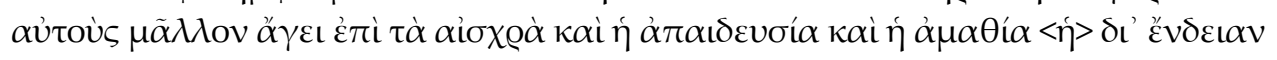

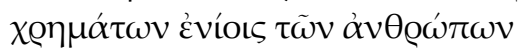

This is a remarkable statement of the cause-and-effect relationship of lack of money ( $\left.\varepsilon^{\prime} v \delta \varepsilon \iota \alpha v \chi \rho \eta \mu \alpha \dot{\alpha} \tau \omega\right)$ ) on penury ( $\left.\pi \varepsilon v i \alpha\right)$ and the effect of poverty on (a)

20. In modern Greece, as in many other countries, this system is applied on a voluntary basis. Greek tycoons have financed the building of hospitals, universities, museums and art centers. They are done efficiently and mostly on time. Nobody can embezzle this funding because he will cheat himself. 
obscenities ( $\alpha i \sigma \chi \rho \dot{\alpha})$; (b) ignorance $(\dot{\alpha} \mu \alpha \theta i \alpha)$; and (c) rudeness ( $\dot{\alpha} \pi \alpha \iota \delta \varepsilon v \sigma i \alpha)$. It is this penury ( $\pi \varepsilon v^{\prime} \alpha$ ) that leads some of the poor people of the Athenian demos to become victims of demagogues and populists. And, in ancient Athens, as in the contemporary world, there was not a short supply of demagogues. Isoteleia then must not only assure that poor people are able to participate in the ecclesia of demos, but guarantee that they are receiving the necessary pedagogy to fulfill their duty as citizens.

In ancient Athens, drama (tragedy and comedy), various religious and cultural festivities and the athletic games played this pedagogical role. Poor people were subsidized to attend the plays at the theaters and participate in the various festivities of ancient Athens. This was a learning process which promoted gnosis with virtue-ethos (arete). There were two other institutions which promoted pedagogy. The private schools of philosophers and the private symposiums organized by the Athenian intellectuals of the time could not be attended by poor and ignorant people. ${ }^{21}$ Unlike Sparta, ancient Athens never implemented a pedagogical system of free education. ${ }^{22}$ Plato's dialogue, entitled Protagoras, gives an excellent discussion on the education system of ancient Athens; both its means and its purpose..$^{23}$ If a strong free pedagogy was provided by the state, it would have made democracy immune to all criticisms that people without gnosis and ethos (arete) were allowed to decide (vote) in the ecclesia of demos, and rule as archons and judges. This aspect has been the most important criticism raised against democracy both in ancient Athens and in the modern world and is further discussed in Papanikos (2021). ${ }^{24}$

Isoteleia was not perfect in ancient Athens. Unlike isonomy, there were many accusations against archons of embezzling and misusing public money and avoiding paying their due taxes. Even Pericles and his well-known friends, who built the Parthenon and other monuments on the Acropolis hill, were accused of mishandling and wasting public money. Unlike what Pericles mentions in his Funeral Oration, sycophants were not absent in a democracy. After all, the word sycophancy originates from ancient Athens. Democracy provided the opportunity to increase the number of sycophants because isegoria gave the freedom of speech which was misused by all those who lacked gnosis and ethos.

21. The problem was not poverty, but ignorance. Socrates was not rich.

22. In ancient Athens there was a public system of education for all its youth but it was only for military purposes for the males from 18 to 20 years old.

23. Plato, Protagoras ( $5^{\text {th }}-4^{\text {th }}$ century BCE).

24. Papanikos, $\triangle \dot{\varepsilon} \kappa \alpha \alpha \alpha \theta \dot{\eta} \mu \alpha \tau \alpha \Delta \eta \mu о \kappa \rho \alpha \tau i \alpha \varsigma, 2021$. 


\section{Isocracy}

All organized societies must have archons who will manage the politeia. Isocracy implies that every eligible citizen must have the same probability to be selected as an archon. Most archons in ancient Athens were selected by a drawing system from a qualified pool of eligible citizens serving for a short period, usually a year. This process not only assured that all citizens had the same probability to be selected, but as many possible could be selected given the short duration and the large number of positions to be filled. In any case, all archons were assessed for their eligibility, arete (ethos) and service to their country by the vouli (parliament) and the court of Athens. Aristotle left us a vivid testimony of this assessment in his Athenian Politeia.

A number of conclusions can be reached from reading Aristotle's masterpiece on the history and characteristics of the Athenian Politeia. The entire assessment was based on three criteria: eligibility, ethos (arete) and civic obligations. Firstly, the archons were asked to verify if they were Athenian citizens. Only those whose parents both were Athenian citizens were qualified. Secondly, the candidates were asked whether they respected the Gods and whether they were treating well their parents. Thirdly, they were asked if they were paying their taxes and had served their military obligations. At the end of this process, anybody was called to say anything against the candidate if there was something to be said. Then, two separate political bodies voted: vouli and court, with two different processes.

The system of having many archons who served for short time periods had additional advantages. Firstly, during the same time period, citizens were serving as rulers (one of the nine archons) and as ruled citizens. As ruled citizens, they should respect the archons who ruled, and of course in return citizens would respect them as rulers. Secondly, since more and more people served as rulers, they acquired more gnosis to be used as citizens to be ruled. Thirdly, the random process restrained any arrogant and egoistic behavior by the rulers because their status was the result of luck. Hubris was something that in ancient Greece was considered as an action against Gods (immoral behavior) and sooner or later nemesis will come. In ancient Athens the ecclesia of demos was very strict on such behaviors and citizens who were considered dangerous to society were ostracized.

Thus, isocracy means that all have the same right and equal probability to serve in public office. Is this the best solution? Of course, it is not. However, Pericles in his Funeral Oration stated that in the Athenian democracy there was:

“... for public offices, everyone wherever prospers, not because where he belongs, but because of his ability, even if he is poor, if he has something good to offer to the city, he is not prevented from serving as an officer"

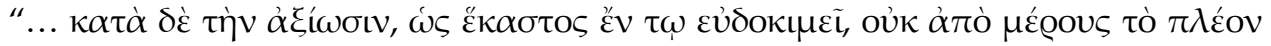

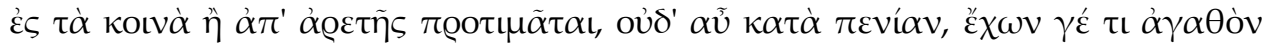

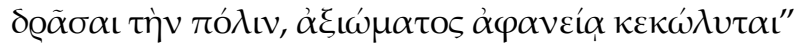


The above statement is really very difficult to interpret because archons were randomly selected. However, not all archons were selected with this process. In ancient Athens isocracy did not preclude those who were good at something ( $\omega \varsigma$

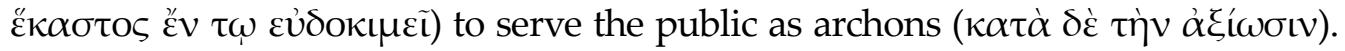
This was definitely the case for military leaders, and in the $4^{\text {th }}$ century BCE the archons were responsible for public finances. Pericles himself served almost every year as an elected archon of the military ( $\sigma \tau \rho \alpha \tau \eta \gamma o ́ \varsigma)$ by the ecclesia of demos. And this had nothing to do with someone's economic situation (oủ ' $\alpha \tilde{u} \kappa \alpha \tau \dot{\alpha} \pi \varepsilon v i ́ \alpha v$ ). After all, Pericles was not poor, but not very rich either.

\section{Isopoliteia}

If one reads the ancient literature of history, philosophy (includes politics) and drama (comedy and tragedy), many excerpts will be found on how to treat the other politeia. If they are treated equal, then this system of international relations can be called isopoliteia.

There are two issues here which might be of interest from democracy's point of view. Firstly, does a democracy have a moral political right to spread democracy even by the use of force? It seems that in ancient Athens such an idea was not rejected. After all, democratic city-states were the allies of the politeia of ancient Athens. Another aspect of the use of force is whether a democratic citystate has the moral obligation to protect a democratic city-state when another state invades it? Secondly, does a democratic city-state justify on ethical political behaviour to attack a smaller and therefore weaker city-state? The ancient literature is ambiguous about this issue even though at its peak of democracy in the second half of the $5^{\text {th }}$ century BCE Athens used its military power for its own advantage. The example of the detriment of the island of Melos is a characteristic implementation of what is today called political realism. The famous Melos dialogue cited in Thucydides' Peloponnesian War is an excellent example of the power of the mighty empires. ${ }^{25}$ Since then the same story repeats itself and it has become what one might call the "iron law of international relations". The iron law is exactly the opposite from what one would normally expect from an ideal democratic state.

Equal treatment of other politeias by a democratic politeia neither existed in the alleged democracy of Ancient Athens nor it exists in the democracies of the modern world.

25. Thucydides, Peloponnesian War ( $5^{\text {th }}$ century BCE). 


\section{Synopsis}

Summarizing the above discussion, a democracy must satisfy all five criteria otherwise it is not a democracy. It can be something else, even better than a democracy. A better system is Plato's utopian politeia, if could ever become a reality. Plato's experience in establishing it in the Greek city-state of Syracuse was a dishonorable disappointment.

All five criteria can be measured using standard quantitative indices for each one of them. Then, an aggregation algorithm can be used to add them up to create one index (measure) of democracy. A composite index of all four can be constructed which will determine the so-called quality of democracy in each politeia. However, adding up the scores of the four sub-indices is complicated. Usually, the summing up is a weighted average of the sum of the scores of the four indices, i.e., a simple additive aggregation. This index then can be used to compare political systems that satisfy all the criteria of democracy. This will be a weak measure of the quality of democracy.

A strong axiom of democracy would require that the aggregation is multiplicative. It would imply that any zero performance in one of the five criteria nullifies the aggregate index of democracy. The construction of such measurable indices goes beyond the scope of this paper and most importantly beyond the

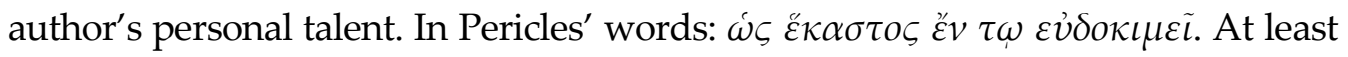
where he thinks he can be fruitful. Does democracy have a future? Yes, but it requires educated citizens, or better citizens with pedagogy, as I argued in Papanikos (2022). ${ }^{26}$

\section{Bibliography}

Aristotle. Athineon Politeia. $4^{\text {th }}$ century BCE.

Aristotle. Politics. $4^{\text {th }}$ century BCE.

Herodotus. Histories (Istoriais). $5^{\text {th }}$ century BCE.

Hesiod. Works and Days. $8^{\text {th }}$ century BCE.

Papanikos, G. T. The Use of European History: Lessons for the 21st Century History. Mimeo, 2005.

. The Use of History as a Tool of Policy-Making. Mimeo, 2006.

. "Taxing Wealth and Only Wealth in an Advanced Economy with an Oversized Informal Economy and Vast Tax Evasion: The Case of Greece." Vierteljahrshefte zur Wirtschaftsforschung, DIW Berlin 84, no. 3 (2015): 85-106.

. What is History? An Assessment of Carr's Monograph. Athens: Athens Institute for Educations and Research (ATINER), 2020.

26. Papanikos, "The Bright Future of Democracy is in Education," Athens Journal of Education 9, no. 2 (2022): 353-364. 


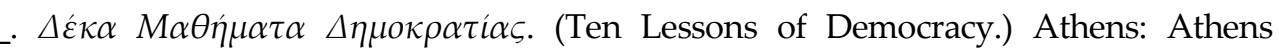
Institute for Education and Research (ATINER), 2021.

. "Collective Decision-Making in Homer's Odyssey." Athens Journal of Mediterranean Studies 7, no. 1 (2021): 59-84.

. "The Bright Future of Democracy is in Education." Athens Journal of Education 9, no. 2 (2022): 353-364.

Papanikos, G. T. and N. C. J. Pappas. European History: Lessons for the 21st Century. Essays from the 3rd International Conference on European History. Athens: Athens Institute for Education and Research (ATINER), 2006.

Plato. Protagoras. $5^{\text {th }}-4^{\text {th }}$ century BCE.

Theophrastus. Characters. $4^{\text {th }}-3^{\text {rd }}$ century BCE.

Thucydides. Peloponnesian War. $5^{\text {th }}$ century BCE.

Xenophon. Lacedaemonian Politeia. $4^{\text {th }}$ century BCE.

. Revenue Sources (Poroi). $4^{\text {th }}$ century BCE.

Xenophon (Pseudo). Athineon Politeia. $5^{\text {th }}$ century BCE. 